\title{
PENGARUH TEKNOLOGI KOMUNIKASI DIGITAL TERHADAP PERTUMBUHAN KARAKTER GENERASI NET DI INDONESIA
}

\author{
Sipra Mariana Gutandjala \\ Mahasiswa Magister Filsafat Keilahian, Fakultas Teologi Universitas Kristen Duta Wacana \\ sipramariana5@gmail.com
}

\begin{abstract}
The progress of this nation is determined by the character of each generation who is the main pillar of a nation. Character that is certainly built on the basis of the recognition of the values and norms of Pancasila as a solid foundation for each generation in playing their roles and responsibilities in the midst of society. However, with the development of technology, a new challenge for the formation of the character of the young generation of this nation. Add to this the presence of a new sparring culture (popular culture) brought by technology increasingly influencing even at times it could erode the local cultural order of the Indonesian nation. This certainly causes a major crisis in the lives of the younger generation because thus the local culture as one of the pillars of defense and a mirror for the young generation now has to deal with the presence of a new counter-culture which will certainly also have a great influence on the lives of the young generation of the nation this. The identity crisis as well as various other social crises will certainly be experienced by the younger generation. Therefore we need serious attention both from educational institutions, religious institutions, social institutions or family institutions in order to provide assistance and think about character education strategies that are right on target for the young generation in Indonesia considering the presence of technology does not only bring positive impacts but technology also brings impacts negative in life so that various efforts to anticipate the future of Indonesia's young generation become urgent and very important thing to do
\end{abstract}

Keyword: Popular Culture, Identity crisis and Social crisis, the role of educational institutions, religion and family.

\section{Pengantar}

Berkembangnya ilmu penge-tahuan mendorong manusia untuk senantiasa menciptakan berbagai penemuan-penemuan baru di segala bidang kehidupan dewasa ini. Hal ini dapat dibuktikan dengan lahirnya teknologi-teknologi cang-gih yang diciptakan oleh tangan ma-nusia sendiri untuk menunjang keberlangsungan hidup manusia di tengah-tengah dunia. Tidak hanya itu saja, terciptanya teknologi sangat mengubah peradaban hidup ma-nusia. Bahwa yang tadinya manusia hanya mengandalkan insting atau hanya membaca tanda-tanda alam untuk menentukan benar-tidaknya suatu fenomena tertentu, sekarang dengan adanya teknologi manusia dapat melakukan apa saja bahkan kecanggihan teknologi dapat mem-buat manusia dengan mudah mengetahui masa depannya meski-pun manusia belum pernah hidup di masa depan. Bersamaan dengan la-hirnya teknologi serta keajaibankeajaiban yang menyertainya, Flippo Tommaso Emilio Marinetti (1876-1944) kemudian mende- klarasikan manifesto Futuris yang menegaskan kematian ruang dan waktu. Marinetti yang tergilagila pada kecepatan menyebut "moralitas kecepatan" sebagai kebudayaan baru. (Pando:2014) Patut kita sadari memang bahwa kecepatan teknologi berdam-pak sangat besar dalam kehidupan ini melalui berbagai perubahanperubahan yang terjadi. Kekha-watiran Marinetti akan kematian ruang dan waktu bukanlah sebuah ilusi belaka melainkan sebuah kepe-kaan yang luar biasa akan kenyataan yang tengah atau akan terjadi. Kecepatan teknologi sudah tentu akan menggiring manusia dari dunia lama yakni dunia fisik menuju dunia baru yakni apa yang kita sebut sebagai dunia maya. Dengan segala tawarantawaran yang menggiurkan, teknologi mencoba menyodorkan kepada kita berbagai hal yang baru semisal kebudayaan baru, tatanan sosial yang baru, gaya hidup baru, bahkan identitas manusia yang baru pula. Tidak hanya itu saja, dengan menyediakan bentuk-bentuk baru komunikasi teknologi adi-cepat me-nyediakan landasan yang kokoh bagi ekonomi-politik kontemporer yang 
mengubah secara dramatik cara orang memperoleh, memanipu-lasi, meneruskan serta menyimpan informasi. Apabila kita tidak mam-pu mengikuti ritme lajunya tekno-logi maka kita akan terserap masuk ke dalam kecepatan dan kebisingan mesin teknologi itu sendiri seba-gaimana yang ditegaskan oleh Melkyar Pando dalam tulisannya bahwa laju teknologi akan bertam-bah sampai batas yang sulit kita bayangkan. (Pando:2014)

\section{Hasil dan Pembahasan}

\subsection{Dinamika Pergaulan Tekno-logi Dengan Kehidupan Ma-nusia}

Bila ada kata yang tepat untuk menggambarkan keadaan masya-rakat di jaman ini, maka kata itu adalah jejaring atau yang kita sebut internet. Manuel Castells dalam salah satu triloginya tentang era reformasi mengatakan bahwa kita hidup sebagai masyarakat jaringan (network society). Artinya kapanpun dan dimanapun kita selalu terhu-bung dengan piranti teknologi kita. Secara mendasar, teknologi diciptakan untuk suatu tujuan atau maksud tertentu. Entah itu untuk membawa sebuah perubahan besar, untuk menguasai atau bahkan untuk menghancurkan tatanan kehidupan yang telah ada sebelumnya. Diperlukan kejelihan serta kekritisan dalam melihat akan ketiga hal ini.Kendatipun demikian, patutlah kita berterimakasih kepada para ilmuwan yang oleh karena anugerah kreatifitasnya telah menciptakan piranti-piranti teknologi kepada kita. Pertanyaan kritisnya, apakah hasil karya mereka ini tidak akan menimbulkan efek samping kepada manusia sebagai penggunanya? Ber-bicara tentang efek samping teknologi komunikasi digital atau internet yang adalah anak kandung teknologi, maka penulis berpikir bahwa kita mesti menentukan de-ngan jelas konteks mana yang akan menjadi sasaran diskusi kita serta seberapa jauh pengaruh teknologi komunikasi digital dalam hal ini internet terhadap kehidupan ma-syarakat di dalam konteks tersebut. Perjumpaan teknologi komunikasi digital dengan kehidupan manusia dimulai di dunia Barat atau dapat kita katakan tempat kelahiran inter-net memang terjadi di dunia
Barat namun penyebaran bahkan pertum-buhan internet sendiri telah sangat bertumbuh subur bahkan menjamur ke seluruh belahan dunia Timur.

Di Indonesia khususnya, per-kembangan internet telah dimulai pada tahun 1990-an. Saat itu jaringan internet di Indonesia lebih dikenal sebagai paguyuban network, dimana semangat kerjasama, keke-luargaan dan gotong royong sangat hangat terasa di antara para pe-lakunya. Agak berbeda dengan sua-sana internet Indonesia pada perkembangannya kemudian yang terasa lebih komersial dan indi-vidual di sebagian aktivitasnya, terutama yang melibatkan perda-gangan internet. (wikipedia:2019) Disadari bahwa penggunaan internet di Indonesia terasa sangat meningkat dalam beberapa tahun terakhir ini. Sebuah survey yang dimuat dalam surat kabar kompas, menunjukan bahwa persentase pengguna internet In-donesia 2016 dalam angka me-ngalami peningkatan per tahunnya. Tahun 2014 hanya 88 juta peng-guna, tahun 2016 tumbuh menjadi 132,7 juta pengguna yang kemudian dipetahkan menjadi $52,5 \%$ peng-gunanya adalah laki-laki, sementara $47,5 \%$ penggunanya adalah perempuan. Itu berarti $51,8 \%$ telah terhubung ke internet, 48,2\% belum merasakan koneksi internet. Kemudian pemetaan berdasarkan region atau wilayah disebutkan dari segi kuantitas, Pulau Jawa masih mendominasi jumlah pengguna internet dengan persentase $65 \%$ setelah pulau Jawa, pulau Sumatera 15,7\%, Pulau Sulawesi 6,3\%, Kalimantan 5,8\%, Bali dan Nusa 4,7\%, Maluku dan Papua 2,5\%. Sementara dari segi usia, diperlihatkan bahwa usia paling melek internet terhitung dari usia 10-14 tahun :100\%, 2024 tahun : 82\%, 25-29 tahun : 80\%. Sebaliknya usia paling gaptek internet terhitung dari usia $50>$ tahun : 3\%, usia 45-49 tahun : 24\%, 40-44 tahun : $46 \%$. Dari segi profesi, dikatakan bahwa penetrasi internet paling tinggi berada di kalangan mahasiswa dengan persentase $89 \%$, karyawan swasta $88 \%$, pekerja kesehatan $85 \%$, PNS $75 \%$, guru/dosen $72 \%$, TNI Polri $72 \%$. Kemudian perilaku pengguna internet Indonesia dapat dipetahkan menjadi 69,9\% mengakses internet dari mobile internet, $13,3 \%$ pengguna mengakses 

internet dari rumah, $11,2 \%$ mengaksesnya dari kantor, 2,2\% mengakses internet dari kampus, $1,6 \%$ mengaksesnya dari warnet, $0,9 \%$ dari café. Selain itu, persentase pengguna internet dengan menggunakan piranti teknologi pribadinya dapat dipetahkan men-jadi $50,7 \%$ pengguna internet mengakses internet via perangkat genggam dan komputer, 47,6\% mengaksesnya via telepon seluler, $1,7 \%$ via komputer. Adapula beberapa alasan utama pengguna internet memilih operator internet tertentu ialah pertama, karena ke-kuatan signal, kedua, karena harga terjangkau, ketiga operator internet itu dirasa hemat, dan keempat banyak memberikan bonus bagi penggunanya. Selain itu, kita dapat melihat juga presentasesitussitus yang digandrungi dan sangat sering diakses oleh para pengguna internet di Indonesia ialah media sosial dengan jumlah 192,2 juta pengunjung/97,4\%, media hiburan 128,4 juta pengunjung/96,8\%, berita 127,9 juta/96,4\%, pendidikan 124,4 juta pengunjung/93,8\%, komersial 123,5 juta pengunjung/93,1\%, layanan publik 121,5 juta pengun-jung/91,6\%. Beralih dari situs-situs yang sering diakses oleh pengguna internet, sekarang kita melihat medsos-medsos (media sosial) yang sering diakses oleh pengguna internet di Indonesia. Survey ini memberikan informasi bahwa media sosial yang menduduki urutan no 1 pengunjung dengan persentase terbanyak ialah Facebook : 71,6 juta pengunjung/54\%, kedua, Instagram : 19,9 juta pengunjung/15\%, Youtube : 14,5 juta pengunjung/11\%. 58,6\% menganggap aman media sosial, 40,5\% menganggap tidak aman media sosial.Ditinjau dari kegunaan media sosial, jumlah pengguna yang menggunakan media sosial untuk berbagi informasi sebanyak 129,3 juta pengguna, yang menggunakan media sosial untuk berdagang sebanyak 125,5 juta pengguna, sementara yang menggunakan me-dia sosial untuk bersosialisasi dengan kebijakan pemerintah seba-nyak 119,9 juta pengguna. Kategori berita yang sering dikunjungi : berita mancanegara 27,3 juta pengunjung. Berita kesehatan 18,2 juta pengunjung, berita kriminalitas 17,7 juta pengunjung. Konten-konten sumber informasi yang sering dikunjungi : Wikipedia 54,1 juta pengunjung, situs keagamaan dan sosbud 23,6 juta pengunjung, situs pendidikan 18 juta pengunjung. Selanjutnya toko belanja online menjadi konten komersial paling banyak dikunjungi: sebanyak 82,2 juta memilih toko belanja online, 45,3 juta memilih bisnis personal melalui akun-akun sosial media mereka, 63,5\% pengguna pernah bertransaksi online, 69,4\% merasa aman bertransaksi online. Kemudian belanja online yang paling banyak dilakukan: 34,1 juta pengguna media sosial memilih membeli tiket secara online. 29,4 juta pengguna media sosial memilih membeli kebutuhan rumah tangga secara on-line dan 4,7 juta memilih membeli pakaian secara online. (youtube:2019) Survey ini baru menunjukan data di tahun 2016. Sementara sudah tentu pengguna internet dengan daya konsumtif yang tinggi mengalami peningkatan setiap tahunnnya. Dengan demikian tidaklah berlebi-han apabila kita mengatakan bahwa tahun 2017 hingga tahun 2019 dapat disebut sebagai puncak keja-yaan teknologi digital. Itu berarti peningkatan pengguna internet masa kini memang tak perlu diragukan lagi.

Kehadiran media digital menembus segala lokus bahkan batas-batas wilayah seluruh belahan dunia ini. Teknologi digital atau tek-nologi komunikasi dalam hal ini internet tidak hanya hadir dan menyapa masyarakat perkotaan saja, melainkan kecanggihannyapun ikut mewarnai bahkan mempengaruhi kehidupan masyarakat pedesaan. Tidak hanya itu saja, kecanggihan internet juga rupanya menembus batas-batas usia, jenis kelamin, ting-kat pendidikan, kelas-kelas sosial, dan profesi setiap penggunanya. Tidak heran jika orang berani mengorbankan apa saja di dunia nyata demi mendapatkan apa yang diinginkannnya di dunia maya. Pertanyaannya, ada apa dengan dunia maya? Mengapa efeknya begitu kuat terhadap perubahan-perubahan yang terjadi dalam kehi-dupan umat manusia dewasa ini terlebih dampaknya terhadap peru-bahan karakter manusia sebagai penggunanya? Pertanyaan ini akan segera terjawab dalam uraian-uraian selanjutnya.

Kemajuan teknologi membuk-tikan bahwa orang bisa dengan mudah mendapatkan apa saja 
yang diinginkannya hanya dengan mene-kan tombol telepon genggamnya atau komputernya. Jika sebelumnya manusia harus berjalan bermilmil atau menghabiskan waktu berjam-jam untuk membeli kebutuhan pokok atau keperluankeperluan lainnya, maka teknologi hadir dan menawarkan sebuah gaya hidup baru dimana hanya dengan duduk sambil berhadapan dengan piranti saja, segala keinginan dapat lang-sung terpenuhi. Itu berarti patut diakui bahwa teknologi mampu me-menuhi segala kebutuhan hidup manusia. Ini barulah persoalan ke-butuhan hidup. Kita belum ber-bicara tentang kekuatan teknologi yang melahirkan budaya hidup instan, teknologi yang membentuk identitas baru, teknologi yang membentuk perilaku hidup manusia bahkan teknologi sebagai sarana berefleksi.

Bagi generasi yang lahir di akhir, pertengahan bahkan bersa-maan dengan masa-masa kejayaan teknologi (generasi X,Y,Z), adanya teknologi tentu dinikmati sebagai bagian dari anugerah Tuhan yang terbaik atas kehidupan ini. Bagai-mana tidak, baik pembangunan karakter hingga pencarian identitas atau jati diri, generasi muda cenderung memilih teknologi sebagai sarana menemukan dirinya. Bagi mereka, kemewahan yang di-bawa oleh teknologi dapat menjadi satu-satunya sumber jawaban yang sangat mungkin, terdekat dan tercepat atas berbagai pertanyaan-pertanyaan mereka yang mungkin saja tidak dapat dijawab oleh realita fisik. Tidak heran mengapa tekno-logi sangat digandrungi bahkan dapat dikatakan teknologi menjadi rumah utama bagi generasi muda.

Salah satu dari sekian banyak keunggulan teknologi ialah menawarkan berbagai kemudahankemudahan bagi manusia. Beberapa dampak positif dari teknologi di dalam kehidupan manusia ialah dapat menjadi media manusia untuk memahami budaya orang lain tanpa perlu pergi ke tempat dimana bu-daya itu lahir atau bersusah payah mempelajari suatu budaya tertentu. Selain itu teknologi juga dapat memperbaharui pemahaman kita tentang gender sehingga membuat kita menjadi lebih terbuka terhadap keragaman yang ada. Hadirnya teknologi juga berguna dalam menopang berkembangnya sektor pariwisata. Meskipun begitu, patut-lah kita pertambingkan apa yang disampaikan oleh Pando yakni ambiguitas sosial terhubung. Bahwa dunia internet atau yang oleh Pando disebut sebagai sosial terhubung pada dasarnya berwajah ambigu. Se-kejap ia menjadi sarana yang sangat mendukung dan menguntungkan bagi siapa saja. Tak diduga ia juga menggerus keutuhan dan kemandi-rian pribadi manusia yang punya nalar untuk berpikir dan hati untuk merasa-rasakan dan menimbang-nimbang. Ambiguitas ini menampil-kan dua wajah yang berbeda walau-pun dengan perangkat teknologi yang sama. (Pando:2014) Pando mengarahkan pandangan kita untuk melihat dan memahami wajah pertama dari jaringan sosial terhubung yang disebut dengan istilah Arab Spring, sebuah istilah untuk menggambar-kan gerakan revolusioner kerusuhan demonstrasi yang terjadi di Timur Tengah sejak tahun 2010. Jaringan sosial terhubung bahkan mampu menjatuhkan kediktatoran rezim yang bertindak semena-mena, ko-rupsi, pelanggaran hak asasi. Di sisi lain, kitapun mesti menyadari kekhasan wajah lain dari jaringan sosial terhubung yang juga dipa-parkan oleh Pando yakni wajah kedua dari jaringan sosial terhubung yang mana bisa mempersempit hidup kita, membuat kita miskin dalam makna dan kurang perhatian pada yang lain karena apa yang dipikirkan adalah identitas yang ingin ditampilkan. Menyambung apa yang disampaikan oleh Pando, menurut pandangan penulis, jari-ngan sosial terhubung tidak hanya mempersempit hidup kita atau membuat kita miskin dalam makna, melainkan lebih lagi, jaringan sosial terhubung dapat pula mengikis habis nilai-nilai budaya, sosial agama bah-kan melahirkan krisis-krisis ideologi dan perilaku dari para penggunanya. Dapat dipahami mengapa pemerin-tah Indonesia mewajibkan pengaja-ran pendidikan pancasila juga pendi-dikan agama sejak Sekolah Dasar hingga Perguruan Tinggi sebagai kurikulum wajib yang mesti diajarkan oleh setiap lembaga-lembaga pendidikan di tanah air. Per-tanyaannya, apakah strategi pemerintah ini berhasil mengatasi krisis-krisis yang dialami para pengguna jaringan sosial terhubung 
khususnya generasi muda? Ataukah strategi pemerintah ini justru tidak berpengaruh terhadap pendidikan karakter dan moral generasi muda dalam menghadapi tantangan-tantangan hidup di era digital?

Era digital telah menawarkan sebuah kebudayaan baru yang dikenal sebagai kebudayaan populer (budaya populer). Dengan adanya kebudayaan baru ini maka Indonesia menghadapi sebuah tantangan yang serius dan terbilang baru pula. Lambat atau cepat, suka ataupun tidak, ketegangan yang terjadi akan mengantarkan Indonesia pada sebuah perenungan mengenai bagai-mana manusia Indonesia terlebih generasi muda Indonesia memaknai kembali kebudayaan Indonesia dalam konteks hidup berdampingan dengan budaya yang baru ini? Bercermin dari dunia Barat, saya pikir sudah saatnya dunia Timur dalam hal ini Indonesia mulai berpikir dan menyadari dengan sungguh berbagai perubahanperu-bahan yang terus terjadi di era ini baik perubahan dalam segi gaya hidup, karakter, pandangan, nilai dan norma bahkan perubahan dalam gaya beragama setiap individu-individu yang ada. Sehingga tidak hanya kebudayaan yang berhadapan dengan dilema ini melainkan agamapun demikian. Agama yang selama ini diyakini sebagai salah satu wadah pembentuk karakter setiap pemeluknya, kini harus berhadapan dengan tantangangan yang dibawa oleh teknologi atau yang oleh Dawson disebut sebagai krisis di zaman modern ini. Dalam uraiannya, Dawson mengatakan bahwa kita mesti peka dengan berbagai tanda-tanda krisis di jaman ini. Menurutnya ada beberapa tanda-tanda krisis di jaman ini diantaranya ketidakpastian ekonomi, ketidaksta-bilan global, kemajuan teknologi, dan transisi demografis yang berlimpah. (James Emery White:2017) Dirinya menekankan bahwa sadar atau tidaknya, gereja akan senantiasa berhadapan dengan krisis-krisis ini dan jika gereja tidak mampu menyikapinya maka gereja akan kehilangan kesempatan. Daw-son berbicara juga tentang persoalan yang urgent di zaman ini, bahwa sebetulnya persoalan yang sangat mendesak di zaman ini ialah persoalan kemanusiaan.Tidak heran apabila generasi muda yang lahir dalam genggaman teknologi cende-rung lebih tertarik pada masalah-masalah kemanusian yang disebabkan oleh ulah teknologi semisal cloning manusia dan transeksua-lisme sehingga apabila gereja mengabaikan perannnya dalam hal merespon dengan serius persoalan-persoalan kemanusiaan maka gereja-pun menjadi kehilangan peran sosialnya di tengah-tengah dunia. Jika begini adanya maka muncul persoalan baru bagaimana bisa generasi muda mempercayai gereja sebagai wadah pembentuk karakter generasi muda?

Gereja dalam pewartaannya sudah mesti mengembangkan teo-logi yang sadar jaman dan konteks yang ada. Dengan begitu maka gereja akan semakin mengenali ber-bagai persoalan-persoalan yang ada di dalam gereja terlebih persoalan generasi muda akibat pengaruh teknologi digital yang marak di kalangan generasi muda. Penting bagi gereja untuk kembali memper-timbangkan ulang aturan-aturan serta tradisi-tradisi gereja yang konvensional dan kaku mengingat gereja hidup di tengah-tengah za-man yang kian cepat berubah juga dengan budaya tandingan baru yang kemudian menuntut manusia untuk memilih dan menentukan mana yang harus dipilih. Generasi muda cenderung terbuka terhadap pilihan-pilihan yang ada. Dalam pengam-bilan keputusan atas pilihan-pilihan tersebut, mereka cenderung memi-kirkan segala sesuatu yang praktis, dapat menjawab persoalan dan dekat dengan kehidupan mereka. Pada fase inilah, teknologi digital menjadi semacam solusi dan jalan kebenaran bagi mereka dan bukan gereja. Mengapa teknologi digital menjadi jalan kebenaran bagi generasi muda? Melkyor Pando menjawab dengan mengatakan sebab hanya teknologi digitallah yang mampu memberikan aksentuasi makna hi-dup dalam kehidupan generasi muda apalagi di tengah proses pencarian jati diri. Menurut pengamatan penulis, bagian ini yang belum sepenuhnya disadari oleh gereja. Dengan demikian upaya untuk membangun kesadaran bertelogi yang "melek" konteks dengan segala kompleksitas dan dinamika jaman modern ini serta sebuah kesa-daran berteologi yang rendah hati terhadap kehidupan generasi muda di dalam 
gereja menjadi hal yang penting untuk direfleksikan oleh gereja. Sebab apabila gereja tidak mampu menyadari akan hal ini maka sudah tentu gereja menjadi terasing dari dunia dimana misi pewartaannya pun tidak menyapa dunia. Namun dalam penulisan ini, perlu digaris bawahi bahwa saya tidak akan berbicara panjang lebar tentang corak penataan gereja atau pola spiritualitas generasi muda yang lahir pasca Kristen di bawa asuhan teknologi, melainkan dari penggambaran ini, yang hendak saya sampaikan ialah bahwa generasi muda di era digital ini sedang berada di tapal batas peru-bahan-perubahan yang begitu kuat akibat lajunya teknologi yang menuntut kepekaan dan keseriusan dari berbagai pranata sosial ke-agamaan untuk bersinergi dalam rangka mendidik setiap karakter generasi muda untuk menjadi lebih baik di tengah-tengah derasnya arus teknologi digital di era ini.

Berangkat dari keseluruhan uraian di atas, maka tibalah kita pada sebuah kesimpulan awal bah-wa sejatinya pendidikan karakter bagi generasi muda di tengah-tengah lajunya arus perubahan yang di bawa oleh teknologi di era digital ini, sangatlah penting dan sudah mesti dilihat sebagai sebagai sebuah keharusan untuk dilakukan oleh lembaga manapun baik lembaga-lembaga pendidikan, lembaga-lembaga keagamaan atau bahkan pada lokus yang paling mendasar yaitu lokus keluarga. Saya pikir dengan menyadari akan hal ini secara sungguh-sungguh maka sekurangkurangnya dapat memben-tuk pemahaman generasi muda untuk semakin kritis dan cerdas dalam menyikapi berbagai krisis-krisis yang dibawa oleh teknologi. Jalan pendidikan karakter saya pikir adalah sebuah jalan transformasi atau meminjam istilahnya Ir. Joko Widodo, sebagai sebuah jalan revo-lusi mental. Karena itu menjadi tidak mudah bagi setiap orang yang terpanggil untuk mengmban tugas mendidik karakter anak muda di tengah-tengah fenomena perubahan yang terjadi. Dibutuhkan keseriusan, kepekaan bahkan pengenalan yang baik terhadap setiap generasi yang hidup di jaman teknologi digital ini. Jika mengacu pada pemetaaan James Emery White yang berpen-dapat bahwa generasi yang dilahirkan sekitar tahun 1995 hingga sekitar tahun 2010 dinamakan generasi Z.

\subsection{Meet Generation $Z$}

James Emery White mengata-kan bahwa ada enam generasi yang masih hidup di Amerika hingga saat ini. White mengemukakan bahwa Generasi Z, yang sekarang persen-tasenya mencapai 25,9 \% dari populasi Amerika. Itu bahkan lebih dari era millennium $(24,5 \%)$. Juga lebih dari baby boomers (23,6\%). Pada tahun 2020, generasi $\mathrm{Z}$ akan terhitung memonopoli semuanya. Mereka tidak hanya akan mempengaruhi budaya Amerika, seperti yang akan terjadi pada gene-rasi manapun, mereka justru akan membentuk budaya Amerika. Perta-nyaannya, siapa yang dapat dikategorikan sebagai generasi Z? Masih ada beberapa perdebatan mengenai kepastian generasi ini. Namun pada dasarnya, generasi ini melibatkan mereka yang dilahirkan setelah generasi $\mathrm{Y}$, jadi sekitar tahun 1995 hingga sekitar tahun 2010. Generasi ini secara kolektif berusia di bawah 25 tahun. Menurut White, mereka tumbuh di dunia pasca peristiwa 9/11. Mereka mengalami perubahan yang radikal dalam teknologi serta memiliki pemahaman yang mema-dai tentang keluarga, seksualitas, dan gender. Mereka dibesarkan di tengah-tengah lingkungan keluarga yang multigenerasional. Berikut adalah lima karakteristik yang me-nonjol dari generasi $\mathrm{Z}$ yakni tanda kemerosotan, Wi-Fi Enabled, multi-rasial, sexually fluid, dan Pasca-Kekristenan. Adapun laporan lain bahwa generasi $\mathrm{Z}$ tampaknya tidak beragama seiring bertambahnya usia mereka. Anilisis ini setidaknya da-pat kita temukan di dunia Barat dan kurang lebihnya dipengaruhi oleh pemahaman sekularisasi di dunia Barat. Dengan demikian maka tidaklah berlebihan untuk dikatakan bahwa di dunia Barat, bukan agama yang menentukan pola perilaku atau karakter generasi Z melainkan tek-nologilah yang melakukan pekerjaan ini.

Indonesia sebagai sebuah nega-ra, tidak menganut paham sekulari-sasi sama seperti dunia Barat, namun melihat realita beragama di Indonesia serta penetrasi teknologi yang terjadi 
begitu kuat di Indo-nesia, saya pikir dalam konteks Indonesia, karakter generasi Z (generasi Net) di era digital ini telah sangat dipengaruhi oleh kehadiran teknologi digital dalam kehidupan generasi Net. Salah satu krisis yang sangat berpotensi membunuh karak-ter generasi $\mathrm{Z}$ di Indonesia ialah krisis relasi sosial. Terhadap gene-rasi yang lahir bersamaan dengan teknologi digital, kerentanan ini terjadi dikarenakan teknologi telah membawa sebuah budaya tanding baru yakni budaya individualistis atau apa yang diistilahkan oleh Melkyor Pando sebagai alone together. Generasi Z di era ini dengan kepekaannya dan kecerda-sannya dalam bergaul dengan teknologi digital kemudian lebih cenderung mempercayai relasinya dengan piranti komunikasi atau media sosialnya ketimbang relasinya secara nyata dengan orangorang di dunia nyata. Bagi mereka, ke-nyataan di dunia nyata tidak seindah kenyataan di dunia maya. Sherry Turkle bahkan telah menyingkap adanya konstruksi identitas dalam komunitas maya. Ia menyimpulkan adanya hasrat untuk selalu terhubung (always online) yang di-bangkitkan oleh kehadiran media sosial dan dunia maya. Manusia tidak hanya terpana menyaksikan kemajuan teknologi, manusia ingin menjadi bagian dari kemajuan itu. Akhirnya sebuah fenomena baru pun lahir, berupa ketergantungan seseorang terhadap piranti canggih yang dapat mengakses segala kebutuhan serta untuk tetap bisa terhubung dengan orang lain. (Pando:2014) Selain budaya selalu terhubung, kita sekarang hidup di tengah-tengah apa yang dinamakan sebagai budaya komentar (coment culture). Budaya ini hadir sebagai respon atas salah satu budaya lainnya yakni budaya berbagi (sharing culture). Great Lovink berusaha membedakan kedua budaya ini dengan mengatakan bahwa budaya berbagi menu-njuk ke inisiatif subjek yang mem-bagikan informasi sedangkan bu-daya komentar (coment culture) lebih menunjuk kepada tanggapan subjek atas postingan yang dibagi-kan oleh orang lain. Tidak mustahil bahwa eksistensi seseorang dinilai dari seberapa sering ia memberi komentar atau berbagi informasi dalam jaringan sosial terhubung. Dalam kesendiriannya, seseorang mencari persetujuan orang lain ataupun dukungan dari orang lain.
Turkle menyebut paradoks ini seba-gai alone together. Saya pikir apa deklarasi yang disuarakan oleh Ma-rinetti tentang kematian ruang dan waktu perlu kembali ditegaskan disini bahwa media sosial terhubung telah membunuh ruang dan waktu. Katakanlah saja bahwa memang piranti teknologilah yang menjadi labuan generasi muda mendambat-kan seluruh kehidupan mereka untuk memperoleh apa yang mereka butuhkan. Realitas fisik seakan tidak berguna lagi bagi generasi ini. Semangat gotong royong, saling menolong, kepekaan dan kepedulian sosial, kehadiran bagi orang yang membutuhkan tentu telah terkisis habis ditelan pesona jaringan sosial terhubung. Kecanduan kepada dunia maya memang membuat orang mati rasa kepada sesamanya, membuat orang menderita penyakit kepedu-lian sosial. Jika demikian yang terjadi maka bagaimana bisa karakter seseorang dikatakan benar-benar karakter apabila orang itu tidak memiliki hati sosial? Sementara menurut pemikiran saya, karakter seseorang hanya dapat dibangun apabila orang itu menyadari eksis-tensi dan keterhubungannya dengan dunia nyata dan bukan dunia maya. Menghidupi realsinya dengan reali-tas dunia nyata dan bukan dunia maya. Hal ini akan terjadi apabila orang menyadari kehadirannya seba-gai bagian dari realitas fisik itu sen-diri, mengabaikan realitas fisik pa-dahal dirinya sedang hidup di dalam bentangan realitas fisik sejatinya adalah jalan untuk membunuh ka-rakter. Ketika keseimbangan antara dunia maya dengan dunia nyata mu-lai hilang maka yang terjadi adalah krisis diri. orang dapat dengan mu-dah memanipulasi diri sedemikian rupa dan menciptakan topeng diri-nya di dunia maya, kemu-dian me-manipulasi diri sedemikian rupa ketika harus kembali ke dunia nyata. Sehingga saya merasa harus mem-benarkan ungkapan lama yang mengatakan bahwa dunia ini ha-nyalah panggung sandiwara. Be-gitulah wajah dunia kita sekarang. Dunia yang kering akan sentuhan rasa sosial yang tinggi. Dunia yang rentan membuat krisis jati diri berkepanjangan. Dunia yang sewak-tu-waktu bisa saja membunuh karakter generasi muda (generasi Z). Dunia yang kian telanjang mulai menampilkan wajah ambiguitasnya kepada manusia terelebih kepada 
generasi Z. Dengan demikian maka dalam upaya mendidik karakter generasi Z, selain pengenalan terhadap kekhasan generasi Z, dibu-tuhkan pula apa yang namanya ke-hadiran untuk mendengarkan apa yang menjadi pergumulan generasi Z. Saya pikir penyebab mendasar generasi $\mathrm{Z}$ tidak menaruh keper-cayaan terhadap realitas sosial dan memilih mengasingkan diri dari dunia sosial ialah karena kurangnya telinga yang diberikan untuk men-dengarkan keluh kesah terkait gejolak psikologis yang dialami oleh generasi ini. Kurangnya kehadiran langsung dari pilar-pilar sosial yang memiliki andil dalam proses men-didik karakter generasi $\mathrm{Z}$ katakanlah pilar lembaga pendidikan, lembaga agama bahkan lembaga keluarga. Sehingga diskusi-diskusi mengenai sejauh mana pengaruh teknologi terhadap perkembangan karakter generasi $\mathrm{Z}$ tidak hanya dilihat seba-gai suatu utopia semu, melainkan sudah mesti mendapat perhatian serius dalam setiap diskursus yang dibangun dengan kesadaran bahwa sebuah aksi transformasi tidak akan pernah terjadi apabila kita terus menerus menutup mata, menutup telinga dan mengasingkan diri dari berbagai krisis-krisis yang tengah terjadi dalam kehidupan dewasa ini.

\section{Kesimpulan}

Pergaulan antara teknologi dengan kehidupan manusia memang terbilang sangatlah dekat. Bagaimana tidak, teknologi diciptakan oleh tangan manusia dengan tujuan untuk kepentingan manusia. Meskipun demikian tak dapat dipungkiri bahwa kedekatan inipun kerapkali menimbulkan pergesekan-pergesekan antara keduanya. Begitulah sebuah pertemuan memang selalu beresiko. Teknologi yang hadir dan melahirkan budaya barunya akan selalu berhadapan dengan budaya bangsa ini. Hal ini bukan berarti keduanya mesti saling dipertentang-kan terus menerus atau salah satu harus mendominasi yang satunya. Dua kebudayaan ini mestilah di-perjumpakan dalam sebuah ruang dialog yang terbuka dan setara untuk saling mengisi. Perjumpaan kedua budaya ini yakni budaya lokal dan budaya yang dibawa oleh teknologi (budaya populer) jika dibaca dari kacamata yang sehat maka sebetul-nya keduanya ada untuk saling memperkaya satu dengan yang lain. Kesadaran bahwa peru-bahan adalah hal yang sangat dinamis mesti mem-buat menjadi terbuka untuk men-dengarkan suara-suara budaya yang lain juga tidak terkecuali suara budaya populer.

Kini karakter generasi muda dibentuk tidak hanya oleh budaya lokal melainkan juga oleh budaya populer. Apalagi generasi $\mathrm{Z}$ sebagai generasi yang lahir dan dibesarkan di dalam genggaman teknologi su-dah barang tentu separuh hidup me-reka sangat diwarnai dengan warna warni budaya populer ketimbang budaya lokal. Hibriditas kebudayaan yang terkandung di dalam diri generasi ini membuat mereka berbe-da dari generasi-generasi yang lain. Tidaklah adil juga apabila kita terus menghakimi dan menyalahkan me-reka atas setiap perilaku, cara ber-pikir atau gaya hidup generasi ini yang mungkin berbeda dari gene-rasi-generasi sebelumnya atau bah-kan bertentangan dengan aturan, nilai dan norma sosial yang telah ada. Biar bagaimanapun, patutlah dipahami bahwa generasi $\mathrm{Z}$ yang adalah anak kandung teknologi me-mang memiliki corak dan kekhasan tersendiri. Dibalik wajah yang sedang ditampilkan oleh generasi $\mathrm{Z}$, generasi ini sebetulnya memiliki ke-peduliaan yang tinggi terhadap persoalan-persoalan kemanusiaan. Generasi yang dengan lantang menentang tindakan pelanggaran moral yang diakibatkan oleh teknologi itu sendiri.

\section{Ucapan Terima Kasih}

Pada kesempatan ini, terimakasih saya ucapkan kepada redaktur yang telah memberikan masukan yang berharga sehingga tulisan ini dapat disajikan di jurnal Institutio. Terimakasih juga saya ucapkan kepada seluruh dewan redaksi jurnal Institutio yang sudah memberikan ruang diskusi. Semoga bantuan dan dukungannya mendapatkan balasan yang sebanyak-banyaknya dari Tuhan kita Yesus Kristus, Amin. 


\section{Pustaka Acuan}

Heryanto, Ariel (ed.). Budaya Populer di

Indonesia: Mencairnya Identitas Pasca Orde

Baru. Yogyakarta: Jalasutra, 2012.

Ibrahim, Idi Subandy. Budaya Populer sebagai Komunikasi: Dinamika Poscape dan Mediascape di Indonesia Kontemporer. Yogyakarta: Jalasutra, 2011, bab 4-10.

Pando, B. Melkyor. Hiruk Pikuk Jaringan Sosial Terhubung: Refleksi Filsafat Teknologi atas Jaringan Sosial Terhubung. Yogyakarta: Kanisius, 2014.

White, James Emery. Meet Generation Z: Understanding and Reaching the New PostChristian World. Grand Rapids: Baker Books, 2017.

\section{Website}

https://id.wikipedia.org/wiki/Sejarah_Internet Indonesia di akses pada tanggal 21 April 2019, jam 23.30

https://www.youtube.com/watch?v=G2RRVf $\mathrm{kmHo \& t}=35 \mathrm{~s}$ diakses pada tanggal 21 April 2019, jam 23.30 